\title{
Population responses of the Endangered White-breasted Thrasher Ramphocinclus brachyurus to a tourist development in Saint Lucia - conservation implications from a spatial modelling approach
}

\author{
RACHEL L. WHITE, TIMOTHEUS JN. BAPTISTE, ALWIN DORNELLY, \\ MATTHEW N. MORTON, MARK J. O'CONNELL and RICHARD P. YOUNG
}

\begin{abstract}
Summary
Tourism development is one of the main contemporary drivers of habitat loss and fragmentation within the Caribbean Islands biodiversity hotspot. In Saint Lucia, construction of a hotel and golf course within coastal dry forest is directly threatening the largest known subpopulation of the Endangered White-breasted Thrasher Ramphocinclus brachyurus. Understanding how the species is responding to ongoing landscape change and identifying priority sites for conservation are imperative for planning its long-term conservation. In this study, a four year White-breasted Thrasher monitoring dataset (2006-2009) and landscape-scale environmental variables were used to: a) identify, characterise and map spatio-temporal patterns of White-breasted Thrasher encounter rate (an abundance proxy) within and outside the tourist development site; b) determine landscape-scale environmental variables that influence such patterns, and c) produce an island-wide predictive map of potentially suitable habitat. Observed patterns in encounter rates within and outside the development site were consistent with thrashers being displaced from cleared areas of forest and crowding into intact forest patches to the north and west of the golf course. A year after the period of the most extensive habitat clearance, White-breasted Thrasher numbers declined markedly leading to a $55 \%$ reduction in encounter rate within the development site over the four years of the study. The habitat suitability model predicted that a range of sites outside of the known geographic range of the thrasher are potentially suitable, some of which merit further surveys for potentially undetected populations. Given these findings, it is vital that patches of suitable dry forest adjacent to the tourist development are protected and contiguous natural habitat inside the tourist development is preserved.
\end{abstract}

\section{Introduction}

The Caribbean islands are one of the world's richest centres of endemic species and this, coupled with the clearance of nearly $90 \%$ of primary vegetation, has resulted in the region being classed as a global conservation priority (Myers et al. 2000). A major current threat facing Caribbean biodiversity is the rapid and sometimes uncontrolled development of one of the world's largest tourism industries (Wege et al. 2009). Although this growth has not been well quantified spatially, tourism development has resulted in widespread removal and fragmentation of natural vegetation to make way for tourist resorts and associated infrastructure, focused on coastal regions (Christ et al. 2003). The negative impacts on biodiversity are potentially severe and widespread, placing a number of globally threatened species under substantial pressure (BirdLife International 2008, Wege et al. 2009). 
One such species is the "Endangered" White-breasted Thrasher Ramphocinclus brachyurus (BirdLife International 2008), a medium-sized passerine belonging to a monotypic genus within the family Mimidae, and deemed one of the highest-priority bird species for research and conservation action within the Neotropics (Stotz et al. 1996). Found only on the islands of Saint Lucia and Martinique, its threatened status is due to historical declines on both islands, resulting primarily from extensive human-driven loss of coastal dry forest habitat (Temple et al. 2006). Latest estimates suggest the global White-breasted Thrasher population numbers just 1,400-1,700 individuals (Temple 2005, Young et al. 2010).

The endemic Saint Lucian subspecies R. b. santaeluciae has an estimated population size of 1,200 , restricted to two small remnant subpopulations lying on the east coast of the island (Temple 2005, Young et al. 2010). The north-east subpopulation is distributed across 1,700 ha of dry forest and scrubland along the north-east coast and numbers only around 80 birds, concentrated in a series of forested ravines and larger valleys (Temple 2005, Young et al. 2010). The Mandelé subpopulation occupies a 600 ha patch of regenerated dry forest on the central eastern coast of the island (Temple 2005). This subpopulation is limited to the north and south of its range by urban and agricultural areas, and to the east by the sea (Temple 2005). In a westerly and inland direction the forest is largely unbroken and transitions into mesic tropical forest with increasing elevation. More than $90 \%$ of Saint Lucia's (75\% of the world's) White-breasted Thrashers live in this area (Temple 2005), with a subpopulation size of around 1,050 birds (Young et al. 2010).

Saint Lucia's economy is highly reliant upon tourism and its growth is a government priority (Saint Lucia Government Information Service 2008). In 2006, construction of the 240 ha Le Paradis tourist resort was initiated within the White-breasted Thrasher's Mandelé range (BirdLife International 2005). The development site, which is dominated by an 18 -hole golf course, represents roughly $25 \%$ of the global area of occupancy of the species (Temple 2005), and at the onset of construction was home to just over 400 thrashers (Young et al. 2010). Despite retention of as much connected natural vegetation as possible and the set-aside of 14 ha near the northern boundary as a nature reserve (DCG 2008), the development has caused extensive disturbance, clearance and fragmentation of natural White-breasted Thrasher habitat. This was predicted to have a significantly negative impact upon the size and viability of the local thrasher population (BirdLife International 2005).

Notwithstanding its threatened status, only a small (4\%) and peripheral part of the White-breasted Thrasher's Saint Lucia range is currently legally protected within a government forest reserve (Temple 2005). Consequently this species is vulnerable to further development of the dry coastal forest. In 2008, plans were proposed to develop much of the north-east coast of the island (Saint Lucia Government Information Service 2008), a region which holds most of the least modified dry forest and scrubland in Saint Lucia, including White-breasted Thrasher habitat. Recent estimates indicate that tourist development companies will soon own land constituting $42 \%$ of the species's extent of occurrence on Saint Lucia (34\% globally) (Young et al. 2010). Appropriate management of remaining habitat is a clear priority for the long-term survival of this species (Temple 2005).

In this study, we investigated how the White-breasted Thrasher's largest known subpopulation is responding to landscape modification arising from construction of the Le Paradis tourist resort by identifying, mapping and modelling spatio-temporal patterns in thrasher encounter rate (an abundance proxy). In addition, we investigated what constitutes suitable habitat for the Saint Lucian subspecies and identified priority sites for surveys of potentially unknown populations and for habitat protection by developing the first habitat suitability model for the species.

\section{Methods}

\section{Monitoring the White-breasted Thrasher}

In 2006, Durrell Wildlife Conservation Trust in partnership with the Saint Lucian Forestry Department established an annual survey to estimate numbers and map spatial abundance 
patterns of the White-breasted Thrasher within its Mandelé range. The main focus was to monitor the subpopulation and quantify the impact of the Le Paradis tourist development. As the thrasher's north-east range is home to fewer birds, is logistically harder to access and is in an area where no tourist developments currently exist, no monitoring programme has been established there. However, in 2006 the aforementioned partnership conducted a census to estimate the subpopulation size and to determine the proportion likely to be impacted by proposed tourist developments. The survey designs employed at both sites are outlined below, but for a more detailed description refer to Young et al. (2010).

\section{Survey design for monitoring the Mandelé subpopulation}

In a Geographic Information System (ArcView GIS 3.2, Esri Inc., California, USA), a randomly placed grid of sample points spaced $250 \mathrm{~m}$ apart was mapped within the known limits, sensu Temple (2005), of the Mandelé range. Sample points falling within habitats known to be unsuitable (agriculture, open ground and built development; Temple 2005) were removed from the grid. The total area of other habitat within the Mandelé range was calculated as 628 ha (i.e. the area presumed occupied by White-breasted Thrashers). In total, 96 sample points were established within the Mandelé range: 34 within the development site boundary and 62 outside (Figure 1 ).

Between 2006 and 2009, sample points were surveyed twice annually in the dry season between January and March. This is when vegetation is less dense, and therefore detectability of birds should be higher than at other times of the year.

Following recommendations by Lee and Marsden (2008), Buckland et al. (2001) and discussions with fieldworkers in Saint Lucia, thrashers were counted during a 6-minute count period, which started immediately after reaching the point. Six minutes was considered the minimum time needed to observe all birds near the point, whilst minimising the time birds could move towards the point from distances further away (Young et al. 2010). After the 6-minute count was completed, fieldworkers spent five minutes vocally imitating thrasher distress calls (i.e. playback) to attract any birds in the local area towards the point. All thrashers that were observed or heard during this 11-minute period were recorded.

Some construction work, which mainly consisted of localised clearance of vegetation to build access tracks, had started prior to the 2006 survey. Widespread construction work commenced after the 2006 survey resulting in a number of large areas of suitable habitat being cleared within the survey region. Sample points that fell within cleared areas were identified annually and the data from counts performed at these points still included in analyses.

\section{Survey design for the 2006 north-east subpopulation census}

Sample points were selected using a stratified random design. In total, 1oo sample points were visited once: 50 points were allocated at random within ravine areas $50 \mathrm{~m}$ of mapped watercourses $(125.3 \mathrm{ha})$ and 50 points positioned randomly throughout the seasonal dry forest in the rest of the range $(1,454 \mathrm{ha}$ ) (Figure 1 ). The survey protocol was identical to that used for monitoring the Mandelé subpopulation.

\section{Spatio-temporal patterns of the Mandelé subpopulation}

Mandelé range encounter rate (sum of the number of individuals recorded during the point-count and play-back count, divided by the number of visits to the point: an abundance proxy) for years 2006 to 2009 were mapped in ArcMap 9.I $\left(\right.$ ESRI $^{\circledR}$ ArcGIS $^{\mathrm{TM}}$, 2005). Encounter rates were found to be non-normally distributed via $Q-Q$ plots and Shapiro-Wilk tests conducted within ' $R$ ' v.2.8.I (R Development Core Team 2008). Accordingly, non-parametric statistical tests were used for all analyses. 


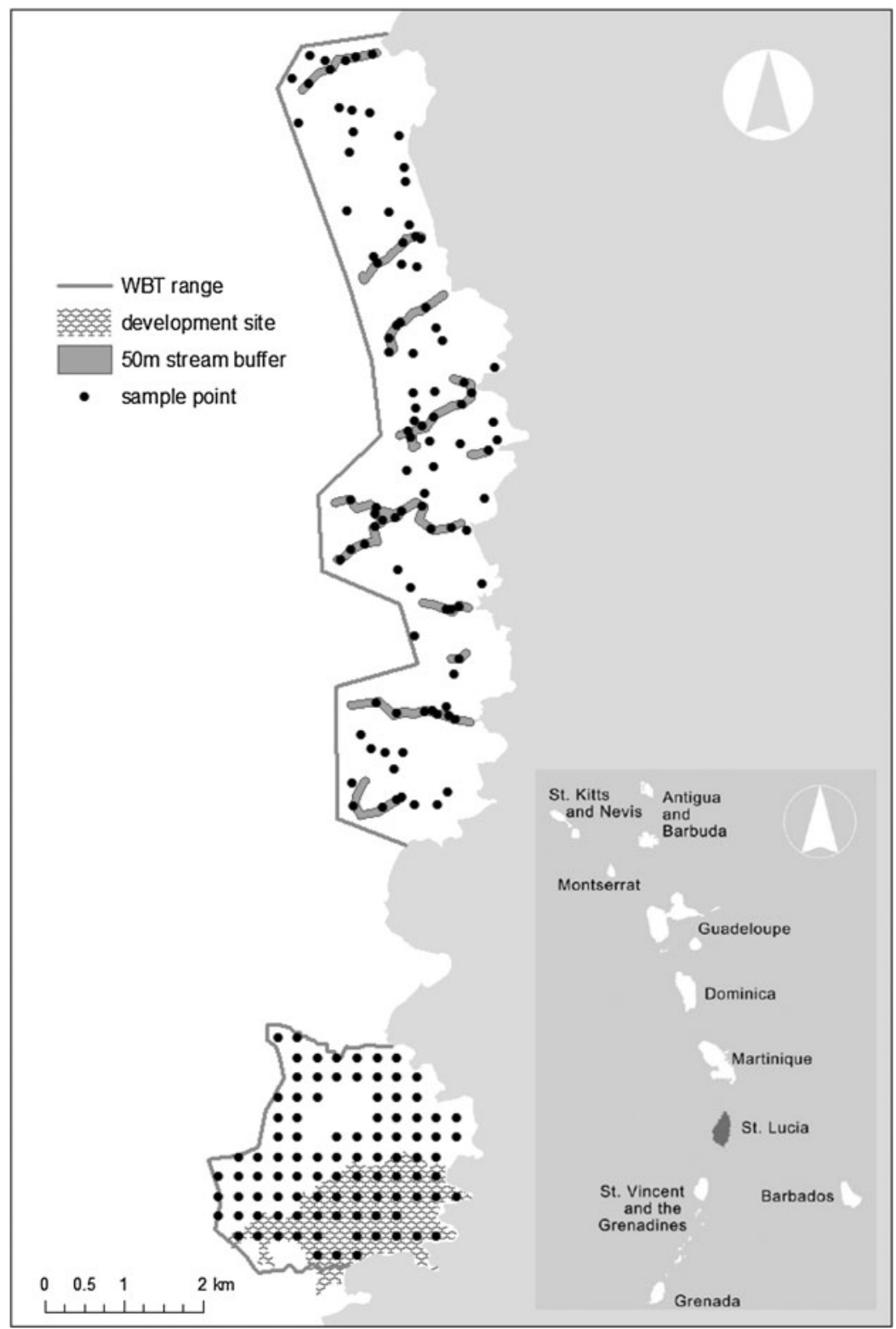

Figure 1. The geographic range of the White-breasted Thrasher (WBT) along the eastern coast of Saint Lucia, divided into north-eastern (most northerly) and Mandelé (most southerly) subpopulations. The Le Paradis development site within the Mandelé range is shown. The position of all 96 sample points annually surveyed in the Mandelé range (34 within the Le Paradis development boundary) are provided, along with the location of all 100 sample points surveyed in the north-east range in 2006 (50 within and 50 outside of ravine habitat). Inset: Saint Lucia's location within the Lesser Antilles.

Wilcoxon signed rank tests were used to determine whether paired encounter rate varied significantly with survey year for all sample points $(n=96)$, development site sample points $(n=34)$ and non-development site sample points $(n=62)$. Differences in encounter rate 
within and outside the development site for each survey year were assessed via Mann-Whitney U tests.

To represent visually and to investigate qualitatively the spatial patterns in White-breasted Thrasher encounter rate, both pre-development (2006) and during development (2007-2009), encounter rate rasters (cell size: $250 \times 250 \mathrm{~m}$ ) for each survey year were created. To visualise temporal change in thrasher encounter rate explicitly, the 'Raster Calculator' tool in ArcMap Spatial Analyst was used to create a raster surface of changes in encounter rates between 2006 and 2009.

\section{Habitat suitability model}

\section{Response variable}

An island-wide habitat suitability model was built using occupancy data from the 2006 Mandelé and north-east range surveys $(n=196)$. This dataset comprised $91(46 \%)$ presences and 105 $(54 \%)$ absences, which were rasterised into $250 \times 250 \mathrm{~m}$ sample cells (the minimum distance between two sample points).

\section{Environmental predictor variables}

Landscape-scale environmental predictor variables were selected based on their recorded potential as determinants of White-breasted Thrasher distribution in the existing literature (Temple 2005). However, inclusion depended upon the availability of appropriate GIS data layers for the extent of Saint Lucia. All processing and extraction of environmental variables were conducted within ArcMap. Table I provides a summary of all environmental predictors used to build the habitat suitability model.

Table 1 . Saint Lucia-wide landscape-scale environmental predictors for habitat suitability model.

\begin{tabular}{|c|c|c|}
\hline Variable & Description & Unit \\
\hline Elevation & Mean elevation within sample cell ${ }^{\mathrm{a}}$ & Metre \\
\hline Slope & Mean slope within sample cell ${ }^{\mathrm{a}}$ & Percentage \\
\hline Aspect_Cosine & $\begin{array}{l}\text { Mean cosine of aspect (north-south axis) } \\
\text { within sample cell }{ }^{\text {a }}\end{array}$ & - \\
\hline Aspect_Sine & Mean sine of aspect (east-west axis) within sample cell ${ }^{\mathrm{a}}$ & - \\
\hline Distance_Coast & Distance of centre of sample cell to nearest coastline & Metre \\
\hline River_Presence & Presence of river or stream within sample cell & - \\
\hline Distance_River & $\begin{array}{l}\text { Distance of centre of sample cell to nearest } \\
\text { river or stream }\end{array}$ & Metre \\
\hline Length_MainRoad & Length of main road within sample cell & Metre \\
\hline Distance_MainRoad & Distance of centre of sample cell to nearest main road & Metre \\
\hline Density_Building & $\begin{array}{l}\text { Mean building density over } 2 \mathrm{~km} \text { window } \\
\text { within sample cell }\end{array}$ & Buildings/cell \\
\hline Distance_Building & Distance of centre of sample cell to nearest building & Metre \\
\hline Temp_Mean & Mean annual temperature within sample cell ${ }^{\mathrm{b}}$ & ${ }^{\circ}$ Centigrade \\
\hline Temp_Seasonality & Temperature Seasonality within sample cell ${ }^{\mathrm{b}}$ & ${ }^{\circ}$ Centigrade \\
\hline Precipitation_Total & Total annual precipitation within sample cell ${ }^{\mathrm{b}}$ & Millimetres \\
\hline VegLand-use & $\begin{array}{l}\text { Dominant vegetation/land-use type } \\
\text { within sample cell }{ }^{\mathrm{c}}\end{array}$ & - \\
\hline
\end{tabular}

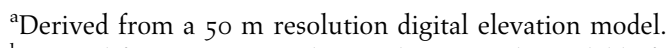

${ }^{\mathrm{b}}$ Derived from $930 \mathrm{~m}$ resolution climate grids available from the WorldClim database v.1.4 (www.worldclim. com) (Hijmans et al. 2005).

'Derived from a 9 class 1984 vegetation map (OAS; organisation of American states). 


\section{Model building and selection}

Prior to modelling, pairwise Spearman correlations were calculated for all environmental predictors to check for multicolinearity. None of the variables were sufficiently correlated $(r>0.8)$ to justify removal from the modelling process.

White-breasted Thrasher habitat suitability on Saint Lucia was modelled using a Generalised Additive Model (GAM; Hastie and Tibshirani 1986) with binomial error structure and canonical logit-link function. Modelling was performed within ' $\mathrm{R}$ ' using the 'Generalized Regression Analysis and Spatial Prediction' (GRASP) v.2.5-7 interface (Lehmann et al. 2008).

A starting GAM including all continuous environmental predictors smoothed with four degrees of freedom was fitted first. Significant environmental predictors were then selected via a backwards and forwards stepwise selection procedure using all possible model permutations. The model showing the lowest amount of residual deviation and the lowest Akaike's Information Criterion value (AIC; Akaike 1974) was selected as the final, most parsimonious model.

To minimise the risk of over-fitting the data (Guisan et al. 2002), all environmental predictors selected in the final model were entered into GRASP using two, three and four degrees of freedom. If explanatory power was maintained despite a reduction in degrees of freedom, the model with lower degrees of freedom was used.

\section{Model evaluation}

The predictive performance of the final model was evaluated via two methods. The first used the Area Under the (Receiver Operating Characteristic) Curve (AUC) (Fielding and Bell 1997). The AUC represents the probability of the model correctly classifying a randomly selected presence point and a randomly selected absence point. AUC values range from o to 1 ; an AUC below 0.5 indicates a model that performs worse than expected by chance, an AUC of 0.5 indicates a model that performs no better than chance, whereas a model scoring 1 fits the data perfectly. The second method used was a 5 -fold split sample validation of the fitted model, a technique similar to, but more robust than jackknifing (Fielding and Bell 1997). Data were divided into five groups drawn at random, then each group dropped in turn and predictions made for the excluded group based on the remaining $80 \%$ of data points.

\section{Spatial predictions}

The habitat suitability map was produced by importing the GRASP prediction output (ASCII format) into ArcMap as a floating-point raster (cell size: 250 x $250 \mathrm{~m}$ ). The map displays the habitat suitability for every complete cell representing the entire extent of Saint Lucia $(n=9,454$ cells). Low suitability equates to $\circ \%$ and high suitability to $100 \%$.

\section{Modelling landscape and spatio-temporal encounter rate patterns of the Mandelé subpopulation}

To investigate landscape characteristics associated with White-breasted Thrasher encounter rate and year-dependent changes in encounter rate within the Mandelé range, additional environmental variables to those in Table 1 were extracted to the Mandelé range sample cells. These additional environmental variables are dynamic in nature (i.e. values change with each survey year).

\section{Dynamic landscape-scale environmental variables}

Neighbouring White-breasted Thrashers: White-breasted Thrashers live in small-social groups, defend year-round territories and disperse short distances, with females dispersing on average 
$360 \mathrm{~m}$ and males $103 \mathrm{~m}$ (Temple 2005). With this in mind, it was hypothesised that the number of thrashers in a given sample cell would be a positive factor of thrasher encounter rate in adjacent sample cells, a product of spatial autocorrelation. As such, the mean number of thrashers seen in the eight adjacent cells for each given sample cell and survey year was determined.

Normalised difference vegetation index: In order to include dynamic variables that show landcover change with time, normalised difference vegetation index (NDVI) was calculated for the entire Mandelé range for each survey year.

Landsat 7 Enhanced Thematic Mapper Plus (ETM+) satellite images (resolution $30 \mathrm{~m}$ ) were obtained online via the Global Land Cover Facility (http://www.landcover.org). In 2003, the system's scan line corrector failed, and since then, raw images have major data gaps along parts of the satellite track. These gaps can be 'filled' using images obtained in near dates. Accordingly, 13 Landsat 7 ETM+ scenes (three to four per survey year) were acquired (Table $\mathrm{S}_{1}$ in the online Supplementary Material). The selected scenes were those with dates as close as possible to each survey that left no gaps after gap-filling, had negligible cloud cover and possessed similarities in grey-scale. All scenes were imported into IDRISI Kilimanjaro (Eastman 2003) for processing, which ultimately led to the production of $30 \mathrm{~m}$ resolution NDVI surfaces of the Mandelé range and close vicinity for each survey year. From these surfaces, mean NDVI and standard deviation of NDVI (a measure of habitat stability; Pettorelli et al. 2005) were extracted for each sample cell and survey year.

Le Paradis development site: Using records detailing whether each sample point was located in intact or cleared habitat for each survey, the following dynamic environmental variables were produced:

1) Sample point intact or cleared of natural habitat

2) Proportion of adjacent cells cleared of natural habitat within development boundary

Table 2 summarises the environmental variables used as input for the Mandelé range models conducted in this study and explained below. To avoid multicolinearity during modelling, pairwise Spearman correlations were calculated for all environmental variables. Distance to coastline was removed as a variable in all subsequent models as it was highly correlated with elevation $(r=0.822, P<$ o.001 $)$.

\section{Mandelé model 1: effect of landscape-scale environment on encounter rate}

To increase understanding of environmental variables that influence White-breasted Thrasher encounter rate, a generalised linear mixed model (GLMM) with Poisson error distribution and canonical log-link function was fitted. Specifically, thrasher encounter rate was modelled as a function of the environmental variables (Table 2), with survey year and sample point fitted as random effects.

\section{Mandelé model 2: effect of landscape-scale environment on change in encounter rate}

To investigate how change in encounter rate over successive surveys was associated with environmental variables and the ongoing Le Paradis development, the difference in thrasher encounter rate for each sample point was calculated between 2006-2007, 2007-2008, and 2008-2009 and the mean value taken as the response variable. Positive values indicate an increase in encounter rate with successive survey year and negative values a decrease in encounter rate. Positive and negative responses were modelled separately via GLMMs with Poisson error distribution and canonical log-link function, as models based on the Poisson distribution cannot include negative response values. These were rendered temporally positive to be incorporated into the model and parameter estimates and Z-values inverted for subsequent interpretation. Specifically, the 
Table 2. Landscape-scale environmental variables used for all three Mandelé range encounter rate models. Dynamic variables shaded in grey.

\begin{tabular}{|c|c|c|}
\hline Abbreviation & Environmental variable & Model/s \\
\hline Elevation & Mean elevation $^{\mathrm{a}}$ & 1,2 \\
\hline Slope & Mean slope $^{\mathrm{a}}$ & 1,2 \\
\hline Aspect_Cosine & Mean cosine of aspect (north-south axis) ${ }^{\mathrm{a}}$ & 1,2 \\
\hline Aspect_Sine & Mean sine of aspect (east-west axis) ${ }^{\mathrm{a}}$ & 1,2 \\
\hline Distance_Coast & Distance to nearest coastline & Removed \\
\hline River_Presence & Presence of river/stream & 1,2 \\
\hline Distance_River & Distance to nearest river/stream & 1,2 \\
\hline Length_MainRoad & Length of main road & 1,2 \\
\hline Distance_MainRoad & Distance of to nearest main road & 1,2 \\
\hline Density_Building & Mean building density over $2 \mathrm{~km}$ window & 1,2 \\
\hline Distance_Building & Distance to nearest building & 1,2 \\
\hline Temp_Mean & Mean annual temperature ${ }^{\mathrm{b}}$ & 1,2 \\
\hline Temp_Seasonality & Mean Seasonality & 1,2 \\
\hline Precipitation_Total & Total annual precipitation ${ }^{\mathrm{b}}$ & 1,2 \\
\hline WBT_Adjacent & Mean thrasher encounter rate in adjacent cells & $1,2,3$ \\
\hline NDVI & Mean NDVI & $1,2,3$ \\
\hline NDVI_std & Standard deviation of NDVI & $1,2,3$ \\
\hline Habitat_Intact & Sample point intact or cleared of natural habitat & 1 \\
\hline Dev_Cleared_Adj & $\begin{array}{l}\text { Proportion of adjacent cells cleared within } \\
\text { development boundary }\end{array}$ & $1,2,3$ \\
\hline
\end{tabular}

${ }^{\mathrm{a}}$ Derived from a $50 \mathrm{~m}$ resolution digital elevation model.

${ }^{\mathrm{b}}$ Derived from $930 \mathrm{~m}$ resolution climate grids available from the WorldClim database v.1.4 (www.worldclim. com) (Hijmans et al. 2005).

Model 1: Effect of landscape-scale environment on encounter rate

Model 2: Effect of landscape-scale environment on change in encounter rate

Model 3: Encounter rate trend with response to landscape-scale environment

magnitude of the numerical change in encounter rate was modelled as a function of environmental variables highlighted in Table 2, with survey year fitted as a random effect.

\section{Mandelé model 3: encounter rate trend with response to landscape-scale environment}

A Generalised Linear Model (GLM) with binomial error structure and canonical logit-link function was used to understand how the overlying trend in thrasher encounter rate was influenced by the ongoing Le Paradis development. Specifically, the model discriminated between environmental variables (Table 2) of sample points that experienced an overall increase or no change in encounter rate, and sample points that experienced an overall decline.

All GLMMs and GLMs were conducted within ' $\mathrm{R}^{\prime}$ and all GLMMs were fitted using the lme4 package (Bates et al. 2008). Minimal adequate models were derived from full 'maximal' models, via a backwards-forwards stepwise selection protocol based on obtaining the lowest AIC value.

\section{Results}

\section{Spatio-temporal patterns of Mandelé sub-population}

A total of 134, 203, 153 and 139 sightings of thrasher individuals and groups were recorded during the four annual Mandelé surveys (2006-2009) respectively.

Encounter rate varied with survey year (Figure 2; Table 3). Between 2006 and 2009, mean encounter rate of all sample points declined by $25 \%$, predominantly attributed to a fall in 


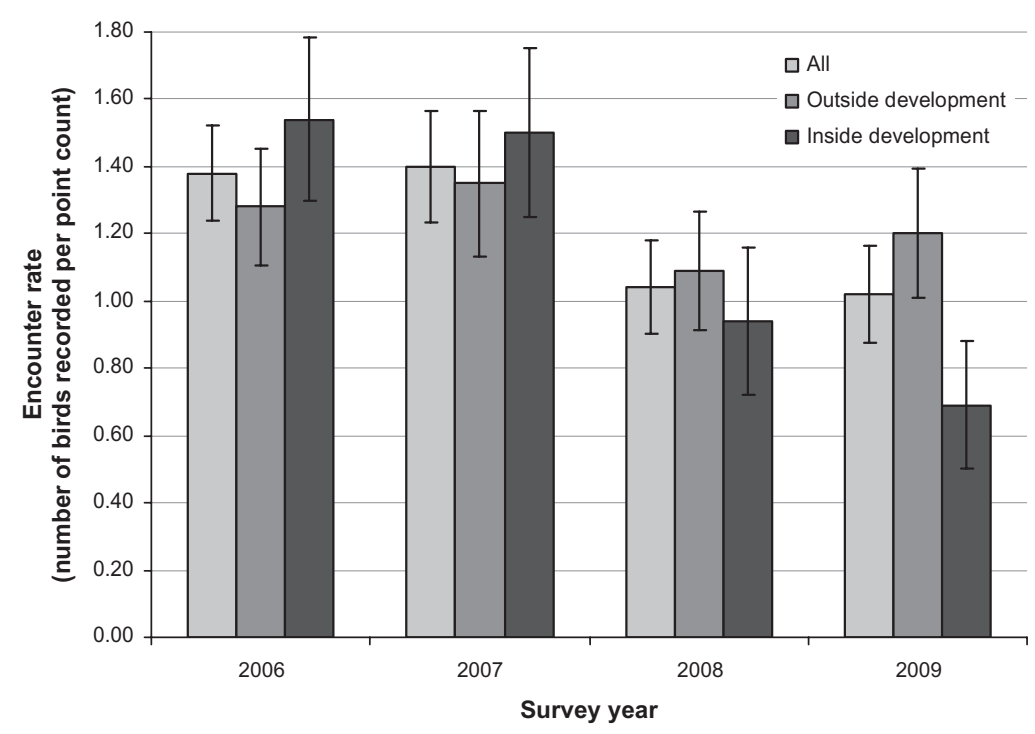

Figure 2. White-breasted Thrasher encounter rate (mean \pm I SE) in the Mandelé range 20062009 surveys. All $=$ all sample points $(n=96)$, outside development site sample points $(n=62)$, and inside development site sample points $(n=34)$.

encounter rate of $26 \%$ between 2007 and 2008 . For sample points outside the tourist development site, encounter rate did not differ significantly with respect to survey year, with only an observed $6 \%$ decline between 2006 and 2009. This was in contrast to sample points within the tourist development site, where encounter rate declined from 2006 to 2009 by $55 \%$, with the most noticeable drop of $37 \%$ occurring between 2007 and 2008. In both 2006 and 2007, encounter rate was greater at sample points in the development site compared to outside, and vice versa in 2008 and 2009, although not significantly.

Figure 3 shows spatial and temporal patterns of White-breasted Thrasher encounter rate in the Mandelé range, for each sample point and survey conducted. In 2006, encounter rates were highest at points in the centre, south and west of the survey region. Between 2006 and 2007, a shift in the distribution of points with higher numbers seemed to occur, with an apparent increase in the numbers of thrashers recorded at points in the west of the Mandele range and a decrease in the east. In both 2006 and 2007, areas of high thrasher density fell inside the tourist

Table 3. Pairwise comparisons (Wilcoxon signed rank tests, $W$ ) of White-breasted Thrasher encounter rate (mean \pm I SE) in the Mandelé range 2006-2009 surveys for all, outside development site and inside development site sample points. Mean and SE reported are the values corresponding to the first year of the associated pairwise comparison. Significant results $(P$-value $<0.05)$ given in bold.

\begin{tabular}{|c|c|c|c|c|c|c|c|c|c|c|c|c|}
\hline & \multicolumn{12}{|c|}{ Encounter rate } \\
\hline & \multicolumn{4}{|c|}{$\begin{array}{c}\text { All } \\
(n=96)\end{array}$} & \multicolumn{4}{|c|}{$\begin{array}{l}\text { Outside development } \\
(n=62)\end{array}$} & \multicolumn{4}{|c|}{$\begin{array}{l}\text { Inside development } \\
(n=34)\end{array}$} \\
\hline & $\bar{x}$ & $S E$ & $W$ & $P$ & $\bar{x}$ & $S D$ & $W$ & $P$ & $\bar{x}$ & $S D$ & $W$ & $P$ \\
\hline 2006-2007 & 1.38 & 1.37 & 1548 & 0.974 & 1.28 & 1.36 & 642 & 0.843 & 1.54 & 1.41 & 200 & 0.800 \\
\hline $2007-2008$ & 1.40 & 1.61 & 1746 & 0.007 & 1.35 & 1.70 & 626 & 0.126 & 1.50 & 1.45 & 286 & 0.020 \\
\hline 2008-2009 & 1.04 & 1.35 & 1085 & 0.937 & 1.09 & 1.40 & 365 & 0.391 & 0.94 & 1.27 & 193 & 0.224 \\
\hline 2006-2009 & 1.03 & 1.40 & 1884 & 0.007 & 1.20 & 1.52 & 638 & 0.437 & 0.69 & 1.11 & 330 & $<0.001$ \\
\hline
\end{tabular}




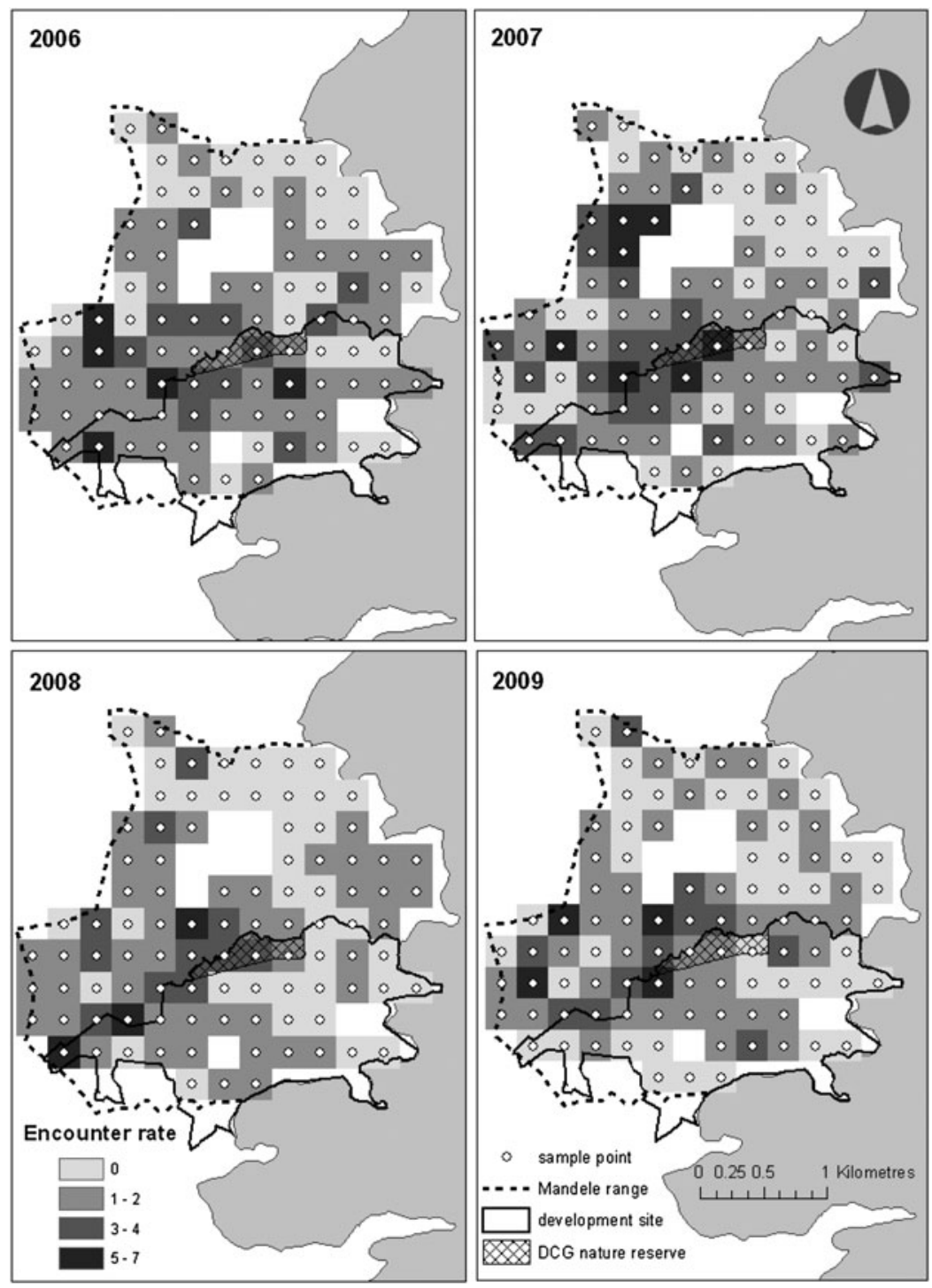

Figure 3. Raster surface of White-breasted Thrasher encounter rate (sum of numbers of individuals recorded during the point count and play-back count, divided by the number of visits to the point: an abundance proxy) for each sample point and survey year in the Mandelé range. Non-surveyed area in the centre of range is built development unsuitable for thrashers; specifically, Bordelais Correctional Facility.

development site. These 'hotspots' were located in the centre of the development in 2006 but shifted to just within the north-west boundary in 2007, moving just outside and on the boundary in 2008 and 2009 respectively. For all survey years, thrashers were noticeably scarce in the north of the Mandelé range, particularly to the north and east of a built development unsuitable for thrashers (Bordelais Correctional Facility, BCF). However, there was an increase in thrasher encounter rate immediately to the south of BCF from 2007 onwards. This area is the north side of the ravine of the River Galet, which forms the northern boundary of the tourist 
development site. The 14 ha nature reserve proposed by the developer DCG is found on the South side of the River Galet and had a consistently high number of thrashers encountered during all survey years.

\section{Habitat suitability model}

Of the 15 candidate environmental predictors (Table 1 ), eight were removed during the stepwise selection procedure, as they conferred no explanatory power to the habitat suitability model. The following seven were retained:

Habitat suitability: River_Presence $+\mathrm{s}($ Distance_Coast,4) $+\mathrm{s}($ Distance_MainRoad,4) + $s($ Density_Building,4 $)+s($ Temp_Mean,4) $+s($ Temp_Seasonality,4) $+s($ Precipitation_Total,4)

Where $s=$ spline smoother; $4=$ degrees of freedom for the spline smoother.

The model had a reasonable fit to the data as the proportion of deviance explained by the model $\left(D^{2}\right)$ was $39 \%$. AUC was 0.90, which indicates excellent model discrimination ability (Swets 1988). An AUC of 0.90 suggests that in the final model, a cell predicted as potentially suitable habitat, at any threshold of suitability, will be more suitable than a randomly selected cell in the study area at least $90 \%$ of the time. The corresponding cross-validation AUC was also high (0.82).

Figure 4 shows the habitat suitability map created with the final model. It can clearly be seen that potentially suitable habitat for the White-breasted Thrasher based on the retained environmental predictors is found in relatively close proximity to the coast and distinctly absent from the central region of the island. The map shows a number of patches of varying levels of habitat suitability along the entire length of the east coast, with hotspots located to the north of the north-east range, between the two currently delineated ranges, within the currently known Mandelé range and nearby vicinity, and in the south-east corner of the island. Substantial areas of potentially suitable habitat were also predicted to occur in the south-west of the island, but were noticeably absent along the north-west coast.

\section{Landscape and spatio-temporal encounter rate patterns of Mandelé sub-population}

White-breasted Thrasher encounter rate was found to be positively associated with the number of thrashers in adjacent sample cells and the proportion of adjacent sample cells cleared of native vegetation within the development boundary, whilst being negatively related to the clearance of native vegetation at a given sample point (Table 4 ).

Six environmental variables were associated with a positive change in White-breasted Thrasher encounter rate with survey year (Table 5). Elevation, west-facing slopes, NDVI, number of thrashers in adjacent sample cells and proportion of adjacent sample cells cleared of native vegetation within the development boundary were positively related to positive change in White-breasted Thrasher encounter rate. However, standard deviation of NDVI was negatively associated with change in thrasher encounter rate, suggesting that sites with high variation in NDVI between years generally had a negative population change. Only standard deviation of NDVI was related to the overarching trend in thrasher encounter rate with advancing survey year, and this was in a negative manner.

\section{Discussion}

White-breasted Thrasher encounter rate (an abundance proxy) declined by $25 \%$ within the Mandelé range in the three years following the start of the Le Paradis tourist resort development, mainly driven by declines inside the development boundary. This result therefore concurs with previous research that shows when tourist developments, including golf courses, replace natural habitat the resulting landscape is of reduced utility to bird species of conservation concern 


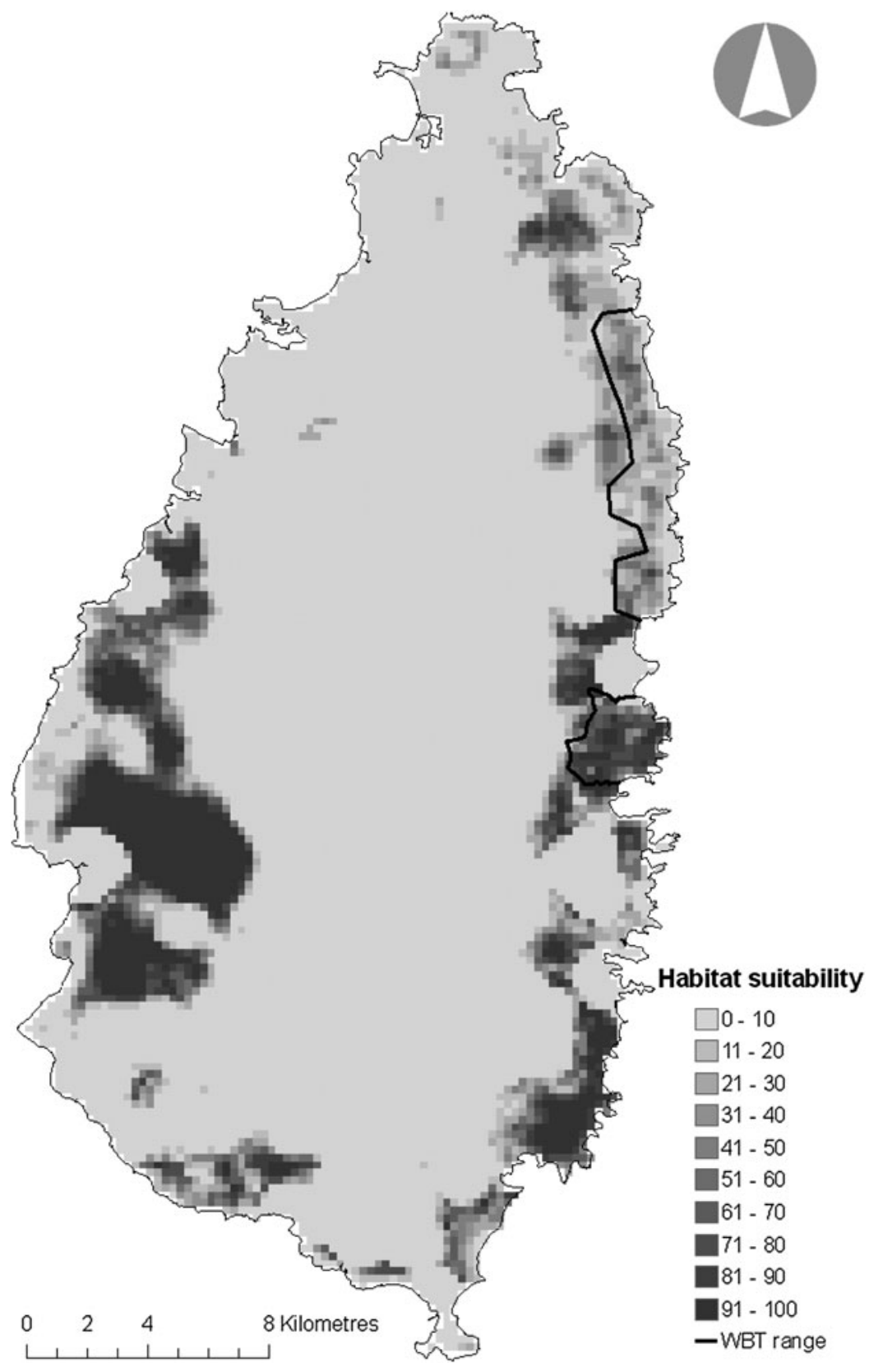

Figure 4. Habitat suitability map for the Saint Lucian White-breasted Thrasher corresponding to the final model. Current delineated range shown.

(e.g. Terman 1997, LeClerc and Cristol 2005, Yasué and Dearden 2006, Hodgkison et al. 2007). White-breasted Thrashers responded negatively to native vegetation clearance within the development site between 2006 and 2009, favouring instead stable and intact areas of dry forest and 
Table 4. Environmental variables that significantly influence White-breasted Thrasher encounter rate, derived from a GLMM. SE = standard error. See Table 2 for variable definitions.

\begin{tabular}{lclrl}
\hline & Parameter estimate & $S E$ & Z value & $P$ value \\
\hline WBT_Adjacent & 0.359 & 0.041 & 8.698 & $<$ O.OOI $^{* * *}$ \\
Habitat_Intact & -1.200 & 0.244 & -4.911 & O.OOI $^{* * *}$ \\
Dev_Cleared_Adj & 1.287 & 0.362 & 3.561 & OO.OOI $^{* * *}$ \\
\hline
\end{tabular}

"-" $=P>0.05,{ }^{*}=P<0.05,{ }^{* *}=P<0.01,{ }^{* * *}=P<0.001$

scrub. This loss of birds in the development area contributed to an overall loss of birds throughout the southern range; it was not compensated for by increases in the area outside the development area, though further population monitoring will determine whether this effect is permanent.

The immediate effects of the vegetation clearance and associated disturbance most probably involved a number of birds being permanently displaced from their territories (Hagan et al. 1996). The distribution maps for 2007 to 2009 (Figure 3) indicate a shift in abundance in a northerly and westerly direction across the Mandelé range, consistent with individuals moving away from cleared areas towards occupied intact habitat. The positive relationship between elevation (which increases westwards across the Mandelé range) and positive change in thrasher encounter rate with survey year provides further evidence of this displacement. Mortensen (2009) also reported an efflux of thrashers from the development area during the nesting seasons (May to August) of 2006 and 2007.

Birds have been shown to increase in population density immediately following habitat loss as displaced individuals crowd into smaller residual fragments (e.g. Bierregaard et al. 1992, Schmiegelow et al. 1997, Debinski and Holt 2000), and the current study suggests such 'crowding' did occur. A positive relationship was found between number of adjacent sample points within the development cleared of native vegetation and: a) thrasher encounter rate, and b) positive change in thrasher encounter rate with survey year. Such crowding is typically followed by a fall in abundance in subsequent years as increased intraspecific competition leads to reduced fecundity and survival (Debinski and Holt 2000). The largest reduction in White-breasted Thrasher numbers occurred between 2007 and 2008, a year after the most extensive period of habitat clearance, suggesting a lagged population response.

The White-breasted Thrasher exhibits a number of life-history traits, which have been shown to predispose species to the detrimental effects of habitat loss and fragmentation (Stouffer and Bierregaard 1995, Canaday 1997, Lens et al. 2002, Sekercioglu et al. 2002). Species that live in social groups, have limited dispersal capabilities and that are ground-foraging forest insectivores have been shown to decline severely in the years following habitat fragmentation. It may be years or decades before the Mandelé subpopulation reaches equilibrium and as Mortensen (2009) points

Table 5. Environmental variables that significantly influence positive change in White-breasted Thrasher encounter rate with survey year, derived from a GLMM. SE = standard error. See Table 2 for variable definitions.

\begin{tabular}{|c|c|c|c|c|}
\hline & Estimate & $S E$ & $Z$ value & $P$ value \\
\hline Elevation & 0.008 & 0.002 & 5.277 & $<{\mathrm{O} .001^{* * *}}^{* *}$ \\
\hline Aspect_Sine & -0.552 & 0.212 & -2.607 & $0.009^{* *}$ \\
\hline NDVI & 2.514 & 0.681 & 3.690 & $<0_{0.001}^{* * *}$ \\
\hline NDVI_std & -3.677 & 1.223 & -3.007 & $0.003^{* *}$ \\
\hline WBT_Adjacent & 0.139 & 0.060 & 2.320 & $0.020^{*}$ \\
\hline Dev_Cleared_Adj & 2.056 & 0.609 & 3.376 & $<\mathrm{o.OOI}^{* * *}$ \\
\hline
\end{tabular}


out: "Extinction debts are likely unpaid within the Mandelé range". Long-lived species with relatively stable population growth rates, of which the thrasher may be a prime example, are predicted to have the highest probability of initially surviving habitat loss, but nevertheless suffering determinate extinction (Kuussaari et al. 2009). It is therefore imperative that it is monitored closely to quantify longer-term impacts and so that conservation efforts are adapted accordingly.

The habitat suitability map provides the first insight into the spatial patterning of potential suitable White-breasted Thrasher habitat across the entire extent of Saint Lucia. As with other habitat suitability modelling studies, choice of environmental predictors was constrained by availability of digital data layers that approximate the realised niche requirements of the study species. Despite this, selected environmental predictors covered a broad spectrum, increasing the likelihood of predicting the thrashers true fundamental niche, resulting in the production of a habitat suitability model with 'excellent' predictive performance (Swets 1988).

Potentially suitable White-breasted Thrasher habitat was predicted to occur around much of the coast of Saint Lucia, with the notable exception of the highly developed north-west coast. Substantial areas deemed potentially highly suitable for the White-breasted Thrasher were identified along Saint Lucia's south-west coast, well outside the known range of the species. These predictions should be treated with caution as they display sharp spatial cut-off points, which can suggest misclassification as a result of extrapolation (Pearson 2007). Extrapolation refers to the use of a model to make predictions for areas with environmental values outside the range of data used to 'train' the model. Resulting predictions may be uncertain, because the model has no prior information regarding the probability of the species's occurrence (Pearson et al. 2006).

The model predicted the existence of potentially suitable habitat adjacent to the south and south-west of the Mandelé range, where occasional thrasher sightings have been made in the past (Temple 2005, Young et al. 2010). The unexpected prediction of an area of potentially suitable habitat occurring between the northern and southern sub-populations may be explained by possible inaccuracies in the GIS data; this area is now dominated by intensive agriculture and urban development and is highly unlikely to be suitable for thrashers. Habitat suitability maps have been used to great effect to guide field surveys to find unknown populations of rare species (e.g. Raxworthy et al. 2003, Engler et al. 2004, Guisan et al. 2006). Although the avifauna of Saint Lucia is relatively well documented, the model's predictions highlight the need for further surveys of sites outside the species's known range. This is particularly important if displaced thrashers have colonised previously unoccupied or infrequently occupied habitat patches following vegetation clearance. In particular, areas to the north of the north-east range and along the south-east coast are worthy of further investigation.

\section{Conservation implications}

The tourist industry in the insular Caribbean has developed rapidly over the past 40 years and today the relative contribution of travel and tourism to GDP is the highest of any region in the world (WTTC 2011). This sector is likely to grow substantially further with travel and tourism demand in the Caribbean region expected to rise from US\$48.6bn in 2011 to US\$70.7bn by 2021 (WTTC 2011). The resulting increased demand on land for resources and construction of tourism infrastructure, mainly concentrated on coastal and marine areas, poses major but unquantified environmental problems for many Caribbean habitats, such as Saint Lucia's dry forests.

The current study demonstrates the short-term impact of a golf course and hotel development along the east coast of Saint Lucia on the already highly threatened White-breasted Thrasher. It underlines the need for immediate efforts to mitigate the impacts of this and other planned tourism developments by protecting suitable habitat adjacent to the Le Paradis development site. Establishing a protected area of dry forest to the north-west and west of the development site 
would encompass areas where thrasher density is highest and is clearly the highest priority conservation action. Protection of suitable habitat adjacent to the development site may also benefit remaining thrashers within the development boundary. Studies have found amount of natural landscape surrounding golf courses to be the best predictor of presence and high abundance-levels of bird species of conservation concern on golf courses (Jones et al. 2005, LeClerc and Cristol 2005, Porter et al. 2005).

The 14-ha nature reserve proposed by DCG is a site that has seen consistently high thrasher encounter rates before and since construction began. The southern slopes of the River Galet ravine that make up this site are immediately adjacent to the northern slopes that have shown consistently higher encounter rate of thrashers since development started. Together with a contiguous area to the west of $\mathrm{BCF}$, these areas seem the most appropriate location for habitat protection and management. Completion of the Le Paradis development however is likely to increase demand for this land for further development.

Given that the majority of the White-breasted Thrasher's range in the Mandelé region occurs in dry forest that has naturally regenerated over the past 30 years from abandoned plantations and farmland (Temple 2005), habitat restoration has been proposed as a long-term conservation intervention to supplement habitat protection measures (Anthony 2005, Temple 2005, Young et al. 2010). It should be noted, however, that despite cessation of golf course construction in 2007, forest regeneration has been largely absent on most of the cleared areas, apparently hampered by severe soil erosion. Thus habitat restoration appears a more realistic opportunity in areas still vegetated (including farmland). The habitat suitability model points to a number of areas both within and adjacent to the known range of the species that may be most suitable for restoration. However, the role of the type of suitability model used in this study is to statistically indicate the spatial distribution of the species's response to variance in the selected landscape features. It is essential therefore that the results are used in conjunction with the ecological knowledge of local conservation practitioners to guide conservation actions.

\section{Supplementary Material}

The supplementary materials for this article can be found at journals.cambridge.org/bci

\section{Acknowledgements}

This work would not have been possible without the dedicated field efforts of SLFD staff and Durrell volunteers: Burt Xavier, Cecilia Orme, Chris Clarke, Donald Anthony, Eleanor Holt, Erica Spayne, Fran Dixon, Kate Statham, Lucy Gillis, Matthew Flavian, Rachael Pedley, Rosie Wills and Ruth Hendry. Special thanks are due to Stephen Lesmond for his essential field assistance over every year of the monitoring. Glyn Young and Hester Whitehead provided much help in establishing the monitoring protocol in the field and we are grateful to Peter Ernest and Kierron Dolby (DCG) for their ongoing help in facilitating these monitoring efforts. Michael Andrew and Lyndon John provided much appreciated support and guidance in managing this work. We would also like to thank the staff and management at Bordelais Correctional Facility for allowing us to monitor points close to the facility. We are very grateful to Peter Long (OxLEL) for his insightful GIS assistance. This work was funded by the Balcombe Trust and the Saint Lucia Ministry of Agriculture, Lands, Forestry \& Fisheries, with funding from DCG to establish the 2006 baseline estimates.

\section{References}

Akaike, H. (1974) A new look at the statistical model identification. IEEE Transactions on Automatic Control 19: 716-723.
Anthony, D. (2005) Mitigative measures to save the St. Lucia White-breasted Thrasher (Ramphocinclus brachyurus sanctaeluciae). 
$<$ http://www.slubiodiv.org/The_Project/ Information/Biodiversity_Papers/Papers2/ Measures_to_Save_the_Thrasher.pdf $>$

Bates, D., Maechler, M. and Dai, B. (2008) lme4: Linear mixed-effects models using $\mathrm{S}_{4}$ classes. $<$ http://lme4.r-forge.r-project. org/>

Bierregaard, R. O., Lovejoy, T. E., Kapos, V., dos Santos, A. A. and Hutchings, R. W. (1992) The biological dynamics of tropical rainforest fragments. BioScience 42: 859-866.

BirdLife International (2005) Hotel development threatens rare thrasher. World Birdwatch 27: 6 .

BirdLife International (2008) Ramphocinclus brachyurus. In: IUCN 2008. 2008 IUCN Red List of Threatened Species. <http:// www.iucnredlist.org $>$

Buckland, S. T., Anderson, D. R., Burnham, K. P. and Laake, J. L. (2001) Distance sampling: estimating abundance of biological populations. London: Chapman and Hall.

Canaday, C. (1997) Loss of insectivorous birds along a gradient of human impact in Amazonia. Biol. Conserv. 77: 63-77.

Christ, C., Hillel, O., Matus, S. and Sweeting, J. (2003) Tourism and biodiversity: mapping tourism's global footprint. Washington DC: Conservation International \& United Nations Environment Programme.

DCG (2008) Working towards a green resort. Paw ol Le Paradis 4(3): 1.

Debinski, D. M. and Holt, R. D. (2000) A survey and overview of habitat fragmentation experiments. Conserv. Biol. 14: 342-355.

Eastman, R. J. (2003) IDRISI Kilimanjaro Guide to GIS and Image Processing. Manual version: 14.00. Clark University Laboratory.

Engler, R., Guisan, A. and Rechsteiner, L. (2004) An improved approach for predicting the distribution of rare and endangered species from occurrence and pseudo-absence data. J. Appl. Ecol. 41: 263-274.

Fielding, A. H. and Bell, J. F. (1997) A review of methods for the assessment of prediction errors in conservation presence/ absence models. Environ. Conserv. 24: 8-49.

Guisan, A., Edwards, T. C. and Hastie, T. (2002) Generalized linear and generalized additive models in studies of species distribution: setting the scene. Ecol. Modell. 157: 89-100.

Guisan, A., Lehmann, A., Ferrier, S., Austin, M., Jacob, M. C., Overton, C., Aspinall, R. and Hastie, T. (2006) Making better biogeographical predictions of species' distributions. J. Appl. Ecol. 43: 386-392.

Hagan, J. M., Van der Haegen, W. M. and McKinley, P. S. (1996) The early development of forest fragmentation effects on birds. Conserv. Biol. 10: 188-202.

Hastie, T. and Tibshirani, R. (1986) Generalized additive models. Statistical Sci. 1: 297318.

Hijmans, R. J., Cameron, S. E., Parra, J. L., Jones, P. G. and Jarvis, A. (2005) Very high resolution interpolated climate surfaces for global land areas. Internatn. J. Climatol. 25: 1965-1978.

Hodgkison, S. C., Hero, J. M. and Warnken, J. (2007) The conservation value of suburban golf courses in a rapidly urbanising region of Australia. Landscape and Urban Planning 79: 323-337.

Jones, S. G., Gordon, D. H., Phillips, G. M. and Richardson, B. R. D. (2005) Avian community response to a golf-course landscape unit gradient. Wildl. Soc. Bull. 33: 422-434.

Kuussaari, M., Bommarco, R., Heikkinen, R. K., Helm, A., Krauss, J., Lindborg, R., Ockinger, E., Partel, M., Pino, J., Roda, F., Stefanescu, C., Teder, T., Zobel, M. and Steffan-Dewenter, I. (2009) Extinction debt: a challenge for biodiversity conservation. Trends Ecol. Evol. 24: 564-571.

LeClerc, J. E. and Cristol, D. A. (2005) Are golf courses providing habitat for birds of conservation concern in Virginia? Wildl. Soc. Bull. 33: 463-470.

Lee, D. C. and Marsden, S. J. (2008) Increasing the value of bird-habitat studies in tropical forests: choice of approach and habitat measures. Bird Conserv. Internatn. 18: Siog-Si24.

Lehmann, A., Fivaz, F., Leathwick, J. and Overton, J. (2008) GRASP: Generalized regression analysis and spatial prediction for $R$. R package version 2.5-7.

Lens, L., Van Dongen, S., Norris, K., Githiru, M. and Matthysen, E. (2002) Avian persistence 
in fragmented rainforest. Science 298: 12361238.

Mortensen, J. L. (2009) Short-term behavioral and demographic responses of the White-breasted Thrasher (Ramphocinclus brachyurus) to habitat loss and fragmentation. MSc thesis, Villanova University, USA.

Myers, N., Mittermeier, R. A., Mittermeier, C. G., da Fonseca, G. A. B. and Kent, J. (2000) Biodiversity hotspots for conservation priorities. Nature 403: 853-858.

Pearson, R. G. (2007) Species' distribution modeling for conservation educators and practitioners. New York: American Museum of Natural History.

Pearson, R. G., Thuiller, W., Araujo, M. B., Martinez-Meyers, E., Broton, L., McClean, C., Miles, L., Seguardo, P., Dawson, T. P. and Lees, D. C. (2006) Model-based uncertainty in species range prediction. J. Biogeog. 33: 1704-1711.

Pettorelli, N., Vik, J. O., Mysterud, A., Gaillard, J-M., Tucker, C. J. and Stenseth, N. C. (2005) Using the satellite-derived NDVI to assess ecological responses to environmental change. Trends Ecol. Evol. 20: 503-510.

Porter, E. E., Bullock, J. and Blair, R. B. (2005) Multiple spatial-scale assessment of the conservation value of golf courses for breeding birds in southwestern Ohio. Wildl. Soc. Bull. 33: 494-506.

R Development Core Team (2008). R: A language and environment for statistical computing. Vienna, $\mathrm{R}$ Foundation for Statistical Computing. <http://www. R-project.org>

Raxworthy, C. J., Martinez-Meyer, E., Horning, N., Nussbaum, R. A., Schneider, G. E., Ortega-Huerta, M. A. and Peterson, A. T. (2003) Predicting distributions of known and unknown reptile species in Madagascar. Nature 426: 837-841.

Saint Lucia Government Information Service (2008) Address to the nation by The Honourable Stephenson King on the state of affairs in the government, June 4 2008. <http:// stlucia.gov.lc/primeminister/statements/2008/ address_to_the_nation_by_the_honourable_ stephenson_king_june_4_2008.htm>

Schmiegelow, F. K. A., Machtans, C. S. and Hannon, S. J. (1997) Are boreal birds resilient to forest fragmentation? An experimental study of short-term community responses. Ecology 78: 1914-1932.

Sekercioglu, C. H., Ehrlich, P. R., Daily, G. C., Aygen, D., Goehring, D. and Sandi, R. F. (2002) Disappearance of insectivorous birds from tropical forest fragments. Proc. Natl. Ac. Sci. 8: 263-267.

Stotz, D. F., Fitzpatrick, J. W., Parker, T. A. and Moskovits, D. K. (1996) Neotropical birds: Ecology and conservation. Chicago: University of Chicago Press.

Stouffer, P. C. and Bierregaard, R. O. (1995) Use of Amazonian forest fragments by understory insectivorous birds. Ecology 76: $2429-2445$.

Swets, J. A. (1988) Measuring the accuracy of diagnostic systems. Science 240: 1285-1293.

Temple, H. J. (2005) Ecology, cooperative breeding and conservation of the Whitebreasted Thrasher Ramphocinclus brachyurus. $\mathrm{PhD}$ thesis. University of Cambridge, UK.

Temple, H. J., Hoffman, J. I. and Amos, W. (2006) Dispersal, philopatry and intergroup relatedness: fine-scale genetic structure in the White-breasted Thrasher, Ramphocinclus brachyurus. Molec. Ecol. 15: 34493458 .

Terman, M. R. (1997) Natural links: naturalistic golf courses as wildlife habitat. Landscape and Urban Planning 38: 183-197.

Wege, D. C., Ryan, D., Varty, N., Anadón-Irizarry, V. and Pérez-Leroux, A. (2009) Ecosystems profile: The Caribbean Islands biodiversity hotspot. Arlington, VA: Critical Ecosystems Partnership Fund.

WTTC (2011) Caribbean: Travel and tourism economic impact. London, UK: World Travel and Tourism Council.

Yasué, M. and Dearden, P. (2006) The potential impact of tourism development on habitat availability and productivity of Malaysian plovers Charadrius peronii. J. Appl. Ecol. 43: 978-989.

Young, R. P., Jn Baptiste, T., Dornelly, A., Temple, H., Whitehead, H., Young, H. G. and Morton, M. N. (2010) Potential impacts of tourist developments in St. Lucia on the endangered White-breasted Thrasher Ramphocinclus brachyurus. Bird Conserv. Internatn. 20: 1-11. 


\section{RACHEL L. WHITE*, TIMOTHEUS JN. BAPTISTE}

Durrell Institute of Conservation and Ecology, School of Anthropology and Conservation, University of Kent, Canterbury, $\mathrm{CT}_{2}{ }_{7} \mathrm{NR}, \mathrm{UK}$.

\section{ALWIN DORNELLY}

Ministry of Agriculture, Lands, Forestry and Fisheries, Government of Saint Lucia, Saint Lucia, West Indies.

MATTHEW N. MORTON ${ }^{\dagger}$, RICHARD P. YOUNG ${ }^{\dagger, \neq}$

${ }^{\dagger}$ Durrell Wildlife Conservation Trust, Les Augrés Manor, Trinity, Jersey, JE3 ${ }_{5} B P$, Channel Islands.

${ }^{\ddagger}$ Department of Biology and Biochemistry, University of Bath, Claverton Down, Bath, BA2 ${ }_{7} A Y, U K$.

\section{MARK J. O'CONNELL}

Ecological Research \& Training Ltd, 4 Peghouse Rise, Gloucestershire, GL5 1RT, UK.

*Author for correspondence; e-mail: rlw22@kent.ac.uk

Received I June 2011; revision accepted I March 2012; Published online 18 May 2012 